\title{
Sexually transmitted diseases in children: chlamydial oculo-genital infection
}

\author{
B T Goh, G E Forster
}

\section{Introduction}

Three species of chlamydia responsible for a wide spectrum of diseases (table 1), are currently recognised: $C$ trachomatis, $C$ psittaci and $C$ pneumoniae; sexual transmission is thought not to occur with the last two. There are at least 15 serovars of $C$ trachomatis. In general, serovars $\mathbf{A}, \mathbf{B}, \mathrm{Ba}$ and $\mathrm{C}$ cause hyperendemic trachoma, serovars $\mathrm{D}$ to $\mathrm{K}$, oculogenital infections and related diseases (table 2) and serovars L1-3 cause lymphogranuloma venereum (LGV); the last two groups of serovars are sexually transmissible. Infection by the D-K serovars affects children of all ages but is uncommon in the prepubertal period. It ranges from perinatal and neonatal infection acquired from the mother, to prepubertal infection as a consequence of long term carriage or voluntary or involuntary sexual intercourse, to sexually transmitted adolescent infection. Infection by the LGV serovars is seen mainly in adolescents with occasional cases reported in prepubertal children.

\section{Historical review}

The aetiology of ophthalmia neonatorum was poorly understood until the discovery of the gonococcus by Neisser ${ }^{1}$ in 1879 which enabled $\mathrm{Kroner}^{2}$ in 1884 to differentiate the nongonococcal "amicrobial" form. Halberstaedter and von Prowazek ${ }^{3}$ first demonstrated the intracytoplasmic inclusions of chlamydia in conjunctival scrapings of trachomatous lesions of man and orangutans in 1907. By 1909 , similar inclusions were found in conjunctival scrapings from babies with ophthalmia ${ }^{4-6}$ and in the genital tract of the parents of such babies. ${ }^{47}$ In 1957, Tang at al isolated the chlamydial agent in egg yolk sacs. The introduction of a cell culture technique by Gordon and Kuan ${ }^{9}$ in 1965 and the microimmunofluorescence method for the detection of antibody and immunotyping by Wang and Grayston ${ }^{10}$ in 1970 enabled widespread study of the epidemiology and clinical

Table 1 Clinical spectrum of chlamydia

\begin{tabular}{|c|c|c|}
\hline Species & Serovars & Diseases \\
\hline$C$ psittaci & A no. of serovars & $\begin{array}{l}\text { Psittacosis, ornithosis } \\
\text { Abortion } \\
\text { Endocarditis }\end{array}$ \\
\hline $\begin{array}{l}\text { C pneumoniae } \\
C \text { trachomatis } \\
C \text { trachomatis } \\
C \text { trachomatis }\end{array}$ & $\begin{array}{l}\mathrm{L} 1, \mathrm{~L} 2, \mathrm{~L} 3 \\
\mathrm{~A}, \mathrm{~B}, \mathrm{Ba}, \mathrm{C} \\
\mathrm{D}, \mathrm{E}, \mathrm{F}, \mathrm{G}, \mathrm{H}, \mathrm{I}, \mathrm{J}, \mathrm{K}\end{array}$ & $\begin{array}{l}\text { Pneumonia } \\
\text { Lymphogranuloma venereum } \\
\text { Hyperendemic trachoma } \\
\text { Oculo-genital and other } \\
\text { infections (table 2) }\end{array}$ \\
\hline
\end{tabular}

spectrum of chlamydial infections.

$C$ trachomatis was first cultured from the cervix of a mother whose baby had nongonococcal ophthalmia in 1959 by Jones, et al. ${ }^{11}$ Pioneering work by Dunlop and associates ${ }^{12} 13$ in the 1960 s confirmed that $C$ trachomatis was an important and common oculogenital pathogen. Extraocular manifestation in infants was probably first described under the entity of pertussoid eosinophilic pneumonia by Botsztejn ${ }^{14}$ in 1941. However, it was not until 1975 that Schachter et al ${ }^{15}$ suggested that $C$ trachomatis could cause afebrile pneumonitis. This syndrome was further characterised by Beem and Saxon ${ }^{16}$ in 1977.

Lymphogranuloma venereum (LGV) was characterised as a separate venereal disease in 1913 by Durand, et $a l^{17}$ who suggested the term "lymphogranuloma inguinale". The introduction of the Frei skin test ${ }^{18}$ in 1925 for the diagnosis of LGV enabled the recognition of its many clinical presentations. The first case report in a child was probably that described by Weiss and Cain in $1925^{19}$ of a 14 year old girl presenting with suppurative inguinal bubo. Additional cases in prepubertal children were reported from 1932 onwards. ${ }^{20-22}$

\section{Epidemiology}

$C$ trachomatis is one of the commonest bacterial sexually transmitted diseases worldwide. This is more so in industralised countries such as the USA and England but may reflect the accessibility of diagnostic facilities. ${ }^{23}{ }^{24}$ Studies on the prevalence of chlamydia in different settings vary considerably and depend on many factors such as the study population and socioeconomic circumstances.

Table 2 Diseases in children caused by $C$ trachomatis

\begin{tabular}{ll}
\hline Neonate: & Adolescent female: \\
Conjunctivitis & Cervicitis \\
Rhinitis & Bartholinitis \\
Pharyngitis & Salpingitis \\
Pneumonia & Endometritis \\
Otitis media & Ectopic pregnancy and infertility \\
Proctitis & ?Cervical intraepithelial neoplasia \\
Premature birth & Adolescent male and female: \\
?Stillbirth & Conjunctivitis \\
& Punctate keratitis \\
Children: & Endemic trachoma \\
Anogenital infection & Cystitis \\
Croup & Proctitis \\
Otitis media & Perihepatitis \\
Myocarditis & Reiter's disease \\
Adolescent male: & Pneumonia \\
Nongonococcal urethritis & Peritonitis \\
Epididymitis & ?Appendicitis \\
\hline
\end{tabular}


Infection in pregnancy and the neonate

The prevalence of chlamydial infection in pregnant women is extremely varied. Reports range from $2-37 \%{ }^{25-33}$ in the USA, $0-33 \%$ in Europe, ${ }^{34-37}$ and $1 \cdot 3-29 \%$ in Africa, ${ }^{38-43}$ the higher figures tending to be amongst inner city adolescents, socially deprived ethnic groups or patients attending STD clinics. In Sweden ${ }^{44}$ the prevalence of chlamydial infection in pregnant women has declined from $19 \%$ in $1984 / 5$ to $2.4 \%$ in 1988 . C trachomatis was isolated from $14 \%$ of women seeking abortion in Singapore ${ }^{45}$ and $13 \%$ and $45 \%$ from pregnant women in Thailand ${ }^{46}$ and $\mathrm{Fiji}^{47}$ respectively.

The annual incidence of chlamydial ophthalmia neonatorum in Kenya is $81 / 1000$ live births $^{43}$ compared with less than $4 / 1000$ life births in the USA. ${ }^{26}$ The prevalence of chlamydia in babies with ophthalmia neonatorum is $49 \%$ in England ${ }^{48}$ and $17-35 \%$ in Africa. 394349

\section{Infection in prepubertal children}

The prevalence of chlamydia in children is mainly based on seroepidemiological studies. In the USA, ${ }^{50-52}$ prevalences range from $10-15 \%$ starting between ages 2 to 9 and increasing with age. ${ }^{53-55}$ This is in contrast to a study in England of children aged 1-15 years which showed a low prevalence below the age of seven with no antibodies above that age. ${ }^{56}$ Correlating serological responses to specific chlamydial infection in seroepidemiological studies is, however, difficult because of the cross reactivity between and within many of the chlamydial species.

\section{Infection in adolescents}

This sexually active group is at greatest risk for chlamydial infection and more so in socially deprived groups and in urban areas. In the USA the prevalence in adolescent males $^{575}$ varies from $9-35 \%$ and in non-pregnant females ${ }^{58-63}$ from $8-25 \%$. Sixteen percent of adolescent girls in residential care in England $^{64}$ and $19 \%$ of sexually active teenage girls in Sweden, ${ }^{65}$ were found to have chlamydial infection.

\section{Lymphogranuloma venereum}

There are very few reported cases of lymphogranuloma venereum in children, where most have been diagnosed on clinical grounds supported by a positive Frei test. However, the antigen used in the Frei test is common to all species of chlamydia, and false positive results may occur. This test is no longer in use. Before 1939, less than 15 possible cases in children aged 3 to 14 years were reported in the literature. ${ }^{66}$ In 1953, Greenblatt et al67 presented a series of 197 consecutive cases from the USA. These included two children aged less than 10 years and 31 patients aged between 11 and 20 years. In 1962, Annamunthodo and Stewart, ${ }^{68}$ reported eight cases in children aged 16 years or under from Jamaica. Buboes were present in two boys and five girls whilst one girl had proctitis. The prevalence of LGV in pregnant women is unknown apart from isolated case reports. ${ }^{69-73}$

LGV is endemic in tropical and subtropical areas of southeast Asia, India, east and west Africa, the Caribbean, and certain parts of the United States and South America. The few sporadic cases reported in Europe are mainly imported. There have been no studies of antenatal and paediatric cases in these endemic areas over the past three decades despite the introduction of more specific tests for LGV.

\section{Routes of transmission}

Transmission may be transplacental, perinatal, accidental or sexual including sexual abuse.

\section{Transplacental}

This is controversial because it is difficult to exclude ascending infection from the cervix and also the evidence is circumstantial, based on the probable effect of chlamydia on the foetus. The transplacental route of transmission was first suggested by the isolation of $C$ trachomatis from spontaneously aborted foetuses $^{74}$ and serological studies of preterm babies with low birth weight but without ophthalmia born to infected mothers. ${ }^{7576}$ This was supported by case reports of intrauterine chlamydial pneumonia in a stillbirth with intact amniotic membranes and in a premature infant who died when aged 4 days. ${ }^{77} 78$ Blood-borne infection from mother to foetus is a possibility as chlamydia is capable of systemic spread as evidenced by a report of $C$ trachomatis endocarditis in a pregnant woman $^{79}$ and some cases of Reiter's disease in which there was evidence of dissemination from the genital tract to the joints. ${ }^{80-82}$

\section{Perinatal transmission}

This is the major route of transmission in neonates. The infection is acquired at birth from the cervix of infected mothers during vaginal delivery. However, infection has been reported in babies delivered by Caesarian section, ${ }^{83}$ usually in association with early rupture of the amniotic membrane where presumably the infection had ascended from the cervix. Babies born to infected women have a $18-50 \%$ chance of developing ophthalmia, ${ }^{25-27} 3084-86$ 8-20\% may develop pneumonia ${ }^{25-27} 308486$ whilst $60-70 \%$ will have some evidence of infection. ${ }^{26278485}$

Different sites such as conjunctiva, nasopharynx and vulvo-vagina can be seeded independently. Once infected, involvement of other sites is usually via contiguous spread or in the case of the rectum, by ingestion of infected ocular or nasopharyngeal material.

\section{Accidental transmission}

Accidental inoculation of infected material from the patients themselves or from infected partners or family members to the eyes or genital tract can lead to ocular or genital infection. A case of chlamydial conjunctivitis in an 18 month old sister of a baby with 
chlamydial ophthalmia neonatorum has been described. ${ }^{83}$ Non-sexual transmission in girls with chlamydial vulvo-vaginitis is thought to occur ${ }^{88} 89$ but sexual abuse cannot be excluded.

\section{Child sexual abuse}

This should be borne in mind in children with chlamydial infection because of the serious implications. Of sexually abused children $4 \%-17 \%$ in American studies have been found to have chlamydial infection. This may be concomitant with gonorrhoea. ${ }^{90-93}$

\section{Voluntary sexual intercourse}

Sexual transmission is directly or indirectly responsible for the spread of infection. Genital infection in older children generally indicates that they are either sexually active or abused. When considering the possibility of child sexual abuse, persistent infection has to be excluded.

\section{Persistent infection}

Chlamydial infection may persist for a long time after perinatal or sexual transmission. Perinatal infection may lead to persistent infection in the vagina, rectum or both for up to three years, and in the pharynx for up to 29 months. ${ }^{94}$ A 17 month old toddler and a 6 year old girl with persistent neonatal chlamydial ocular infection and a 3 year old girl with recto-vaginal infection have been reported; the older toddler also had chlamydial vulvovaginitis. ${ }^{1395}$

\section{Lymphogranuloma venereum}

Lymphogranuloma venereum in children is acquired through sexual intercourse or nonvenereal accidental transmission. ${ }^{6896}$ In the latter, it is difficult to exclude the possibility of sexual abuse. Five cases, all girls aged 4-9 years with rectal involvement, were reported where transmission was probably from sharing the same beds or contaminated fomites from their infected mothers. ${ }^{66}$ A case was reported in an 8 year old girl presenting with proctitis and malaena where an enema tip used by her infected mother was also used for the child. ${ }^{97}$ Transmission through homosexual anal intercourse has been reported in two boys aged $11^{98}$ and $17 . .^{68}$ The older boy had a history of homosexual assault when aged 10 and symptoms of proctitis from age 14. A girl of eleven who acquired both syphilis and LGV following sexual assault has also been described. ${ }^{68}$

There is little evidence of transplacental or perinatal transmission. However, symptomatic and asymptomatic cervical infection have been reported in women. Whether this can lead to perinatal transmission is unknown. The report of the possibility of congenital LGV in a 2 week old healthy baby with a positive Frei test born to an infected mother ${ }^{69}$ is dubious as the Frei test is not specific for LGV. Other isolated reports do not support transplacental transmission. ${ }^{7071}$

\section{Clinical presentation}

Infection in the neonate

Perinatal infection may lead to prematurity, low birth weight 29757699 and possibly stillbirth and neonatal deaths. ${ }^{84} 99$ Although some studies have not shown a relationship with low birth weight, ${ }^{28} 84$ it may be primary chlamydial infection during pregnancy, as evidenced by maternal chlamydial IgM or IgG seroconversion, that is important. ${ }^{100101}$ The IgM may also indicate an active or invasive process. The presence of IgM in chlamydia-culturepositive women has been related to prematurity. ${ }^{102}$ Co-infection with trichomonas was associated with prematurity and low birth weight, ${ }^{33}$ whereas with $M$ hominis, it resulted in increased incidence of spontaneous abortion, prematurity, still birth and neonatal deaths. ${ }^{103}$ Martin et a ${ }^{99}$ reported a 10-fold increase in stillbirths and neonatal deaths based on 18 pregnant women infected before 20 weeks' gestation. This was not confirmed by a larger study which also controlled for age, race, socioeconomic status and other coexisting infections. ${ }^{102}$

The commonest neonatal presentation is purulent conjunctivitis, with an onset at 5-13 days. Neonates with chlamydial ophthalmia may be premature with low birth weight. ${ }^{83100101}$ Gonorrhoea may coexist. ${ }^{4849}$ Chemosis and conjunctival pseudomembranes may be present. If untreated, this may rarely lead to conjunctival scarring and corneal involvement. ${ }^{8106}$ Other sites such as the nasopharynx, lung, middle ear, genital tract and rectum may also be infected ${ }^{107}$ and occasionally lead to symptomatic rhinitis neonatorum, ${ }^{108}$ afebrile pneumonia and otitis media. ${ }^{27} 109110$

Afebrile pneumonia usually presents in the first three months of life with staccato cough, tachypnoea, inspiratory crepitations and hyperinflation. ${ }^{1617}$ It may be subclinical without the characteristic symptoms ${ }^{111}$ and there may not be a history of conjunctivitis. Clinical signs are usually minimal, but a chest radiograph may show diffuse interstitial involvement. There may be an associated eosinophilia or increased serum immunoglobulins. The pneumonia may be severe in babies with low birth weight ${ }^{112}$ and Ig G2/Ig G4 antibody deficiency ${ }^{113}$ and may lead to chronic lung disease. ${ }^{75114}$ Fifty nine percent of infants less than 6 months of age with chlamydial pneumonitis developed middle ear disorders. ${ }^{115}$ Although afebrile pneumonia is more commonly reported in the United States, it is rarely described in the United Kingdom. This may reflect the size of reservoir of chlamydial infection resulting from inadequate chlamydial diagnostic and treatment facilities, the use of ocular prophylaxis against chlamydia after birth which allows extraocular infection to occur and possibly, the high index of suspicion in those hospitals in the United States where the studies were performed.

\section{Infection in prepubertal children}

Prepubertal children can present with urethri- 
tis or vulvovaginitis. ${ }^{135089116117}$ In one study ${ }^{117}$ nine children age 4-11 were found to have dual infection with $C$ trachomatis and $N$ gonorrhoeae. Chlamydia was isolated from either the urethra or rectum in boys and from the vagina or rectum or both in girls. One boy had symptoms of urethritis and two girls had vulvo-vaginal discharge, the rest were asymptomatic. In two cases, asymptomatic chlamydial infection was also seen in four other family members age 4-11 years. A 6 year old girl with chlamydial vulvovaginitis whose mother had chlamydial cervical infection and father had non-specific urethritis has been reported. ${ }^{13}$ Chlamydial recto-vaginal infection in children tends to be asymptomatic, being discovered by routine tests in suspected cases. Sexual abuse has to be excluded.

Whether chlamydia causes otitis media in children and in infants more than 7 months' old is controversial. While most studies ${ }^{118-120}$ show that it plays no role, $C$ trachomatis has been isolated from the middle ear aspirates of children 1-8 years old with otitis media. ${ }^{121}$ Chlamydia-associated myocarditis in children aged one to six years, which was fatal in some cases has been reported. ${ }^{122} C$ trachomatis and Staphylococcus aureus were isolated from the subglottic exudate in a three and a half year old boy with tracheitis presenting with a barking cough, inspiratory stridor and respiratory distress after a two days afebrile upper respiratory tract infection. ${ }^{123}$ Reiter's disease ${ }^{80}$ has been reported in two Canadian Indian boys, aged 2 and 14 years, who also had positive chlamydial isolation from the synovial fluid and urethra respectively. The first boy had arthritis, conjunctivitis and pyuria which was preceded by diarrhoea. The older boy who was sexually active had dysuria, arthritis, enthesopathy, conjunctivitis, balanitis, sacroiliitis and pleurisy.

\section{Infection in adolescents}

Presentation of sexually acquired chlamydial infection in adolescents is similar to adults. Asymptomatic infection is common. Adolescent males present with nongonococcal urethritis (NGU) complaining of urethral discharge and painful micturition. $C$ trachomatis is responsible for up to $50 \%$ of cases of NGU. Epididymitis and Reiter's disease may complicate the infection. Proctitis may result from anal intercourse in males.

The cervix is the commonest site of infection in adolescent girls. There may be mucopurulent cervicitis with follicles, or the cervix may appear normal. Bartholinitis, urethritis, cystitis and follicular proctitis may be seen. The most important complication is salpingitis which may lead to chronic pelvic pain, ectopic pregnancy and sterility. Perihepatitis, leading to right hypochondrial pain, which may or may not be associated with salpingitis, has been reported in adolescent girls age $14-16$ years. ${ }^{124}$

Chlamydial pneumonia has been described in two immunosuppressed adolescents aged 15 and 17 years. ${ }^{125}$ One had a renal allograft, the other had chemotherapy for acute lymphocytic leukaemia. Both had $C$ trachomatis isolated from the lung tissue, eye and nasopharynx.

\section{Lymphogranuloma venereum}

Inguinal lymphadenopathy and proctitis are the commonest presentation in prepubertal children. ${ }^{68} \mathrm{It}$ is rare to find the primary lesion. Occasionally the children may present because an adult member is also affected. LGV may be associated with arthropathy; four cases of arthritis of the knees, one of whom also had swollen ankles, have been reported in a boy aged 11 years $^{98}$ and three girls aged 7, 8 and 12 years. ${ }^{66}$ As in adults cases, erythema nodosum may occur in children. ${ }^{66}$

Sexually active adolescents may present with a primary lesion manifesting as a small transient genital ulcer within 5 weeks of exposure but usually between 2 and 5 days. This is followed by inguinal lymphadenopathy, usually unilateral, which may be multiloculated. Enlargement of the lymph nodes above and below the inguinal ligament may lead to the "groove" sign. The bubo may resolve or rupture forming sinuses. Primary infection of the posterior vaginal wall may involve the rectovaginal septum. Perirectal involvement with proctocolitis may lead to fibrosis, scarring and stricture formation. Genital elephantiasis (esthiomene) may develop with chronic infection.

\section{Diagnostic methods}

The choice of diagnostic method depends upon the expertise and resources available, the prevalence of infection in the population to be tested, the workload, the sites of infection and the purpose of the test.

\section{Microscopy}

Giemsa-stained smears for chlamydial inclusions are only useful for conjunctival specimens because of its poor sensitivity in other sites.

\section{Culture}

Cell culture technique is specific but its sensitivity varies. ${ }^{126-129}$ Confirmation of infection should always be by direct visualisation of stained inclusions and not by the detection of antigen using enzyme immuno assay (EIA) as this can lead to false positives. ${ }^{130}$ The latter should not be considered a "cell culture" technique. Cell culture, although labour intensive, is the method of choice for diagnosing infection in low prevalence populations, for sites other than the conjunctiva, cervix and urethra, for medico-legal purposes and in suspected sexual abuse cases because of its high specificity and positive predictive value.

\section{Antigen detection tests}

Antigen detection tests for clinical specimens using the direct immunofluorescent (DIF) method, (for example Microtrak (Syva, UK)), and EIA (such as Chlamydiazyme 
(Abbotts), IDEIA (Novo Nordisk Diagnostics, UK)), have provided rapid methods with good sensitivities and specificities. ${ }^{131}$

As false positive results may occur especially from anatomical sites where other bacteria may be present, they should not be used in unapproved sites and in medicolegal and sexual abuse cases. ${ }^{132}$ Antigen detection tests should be used with caution in low prevalence populations because of the poor positive predictive value. They may be used to exclude infection because of the high negative predictive value, but a positive result should be confirmed, if possible, by culture. In medico-legal cases, if culture is not available, DIF is the preferred alternative as it can be stored and reassessed.

\section{Methods of specimen collection}

For culture, epithelial cells containing viable organisms are required. Success is dependent upon an adequate sampling technique and proper specimen transportation. In male children, the procedure for obtaining urethral material for culture or antigen detection is invasive and painful as the swab has to be inserted into the urethra. The use of a first catch urine specimen to detect chlamydial antigen using DIF or EIA has recently been shown to be sensitive and specific in a high risk adult population ${ }^{133-137}$ and could be applied to children. If confirmed, this will be a non-invasive way of diagnosing urethral infection.

In lymphogranuloma venereum, bubo aspirate or swab from the ulcer base or rectal lesion should be taken for diagnostic tests, preferably culture. Aspiration of bubo should be performed using a large bore needle through adjacent intact skin to prevent fistula formation. Biopsy of granulation tissue can also be stained for chlamydial antigen.

\section{Serology}

The micro-immunofluorescence method to detect chlamydial antibodies has limited application. It is of use in complicated infections especially when the patient has had antichlamydial suppressive therapy. Serological tests should be interpreted with caution because of cross reaction between the serovars as well as the different chlamydial species. The presence of IgM, or more than a four fold increase in IgG, or high IgG titres $(>1: 256)$ may indicate that the disease is related to chlamydia.

\section{Surrogate markers for chlamydial infection}

If chlamydial diagnostic tests are not available, surrogate markers using the presence of pus cells in the absence of gram-negative intra-cellular diplococci and other bacteria in conjunctival and urethral smears can be used for the presumptive diagnosis of chlamydial ophthalmia neonatorum ${ }^{48}$ and non-gonococcal urethritis including those of chlamydial origin. ${ }^{138}$

A criterion of five to ten or more pus cells per high power field $(\times 1000)$ in urethral material ${ }^{138-140}$ is diagnostic of non-gonococcal urethritis. An early morning smear after the patient has held urine will detect additional cases of asymptomatic urethritis. ${ }^{141}$ First catch urine ${ }^{142}$ and endocervical pus counts ${ }^{143}$ may correllate with chlamydial urethritis and mucopurulent cervicitis respectively but are not supported by other studies. ${ }^{144} 145$

\section{Other techniques}

DNA probes and the polymerase chain reaction (PCR) are still research tools. The DNA probe, although specific, is not sensitive. PCR is extremely sensitive but prone to false positive results if laboratory contamination is not meticulously avoided.

\section{Prevention, treatment and follow up regimes \\ Antenatal screening}

Screening and treatment of pregnant women for chlamydial infection where prevalence is high and in those with casual sexual partners would be the best method of preventing perinatal transmission to babies. It is estimated that it is cost effective to screen women when the prevalence of chlamydial infection is above $7 \% .^{146}$

\section{Neonatal prophylaxis}

The use of ocular prophylaxis by instillation of silver nitrate, erythromycin or tetracycline drops or ointment after birth to prevent neonatal ophthalmia is controversial. The presence of gonococcal or chlamydial ophthalmia neonatorum is a marker that other sites such as the nasopharynx and rectum, as well as the mother and her sexual partner(s), are infected. Furthermore $12-30 \%$ of untreated mothers will develop pelvic inflammatory disease..$^{493147}$ While it has been shown that the use of $1 \%$ silver nitrate (Crede's prophylaxis) drops or tetracycline ointment led to a three fold decrease in the incidence of ophthalmia in Kenya, both treatments did not prevent chlamydial infection of other sites; the onset of pneumonitis between 1-2 months was described in some of the babies. $^{86148}$ Thus ocular prophylaxis incompletely prevents ocular infections, has no effect on other infected sites and the opportunity for contact tracing is lost. In countries where the prevalence of neonatal gonococcal ophthalmia is high with poor health care facilities and limited resources, ocular prophylaxis may be justified to prevent blindness in the babies. This is at the expense of the health of the parents and control of infection. Ocular prophylaxis should strongly be discouraged in developed countries with good health care facilities. Most states in the USA are still required by law to provide ocular prophylaxis, whereas this practice has long stopped in many European countries including the United Kingdom and Denmark. If prophylaxis is to be used, the aim is to prevent blindness from gonococcal ophthalmia. It might, arguably, be an added advantage if it will also cover chlamydial ophthalmia, but current prophylaxis for gonococcal ophthalmia have 
not been effective for chlamydia. ${ }^{86} 149$ Although the cornea may be involved in chlamydial ophthalmia, the risk of blindness is negligible. Furthermore, antibiotics effective against chlamydia are generally poor treatment for gonorrhoea because of the development of drug resistance. If ocular prophylaxis is deemed necessary, $1 \%$ silver nitrate eye drops, $1 \%$ tetracycline or $0.5 \%$ erythromycin eye ointment can be used; silver nitrate is cheaper and as effective but may cause chemical conjunctivitis. It should be instilled immediately into the eyes after birth.

\section{Treatment in neonates}

In infants with chlamydial ophthalmia, treatment is with erythromycin stearate or ethylsuccinate suspension $50 \mathrm{mg} / \mathrm{kg} /$ day in four divided doses before feeds for two weeks. If pneumonitis is present, treatment should continue for three weeks. Once systemic treatment is started, local eye treatment with ocular tetracycline is unnecessary but may speed up healing.

\section{Treatment in children}

Tetracycline should not be given to children under 12 years of age. Erythromycin is the antibiotic of choice. The dosage will depend on the weight or age of patients.

\section{Treatment in adolescents}

The treatment of choice for uncomplicated infection is tetracycline $500 \mathrm{mg} 6$ hourly or doxycycline $200 \mathrm{mg}$ daily either as a single dose or $100 \mathrm{mg} 12$ hourly for 7 days. ${ }^{23}$ For pregnant women and patients who are allergic to tetracycline, erythromycin stearate, base or ethylsuccinate, $500 \mathrm{mg} 6$ hourly, is given for 7 days. For complicated infections such as pelvic inflammatory disease or epididymitis, treatment is for 3 weeks. Azithromycin, an azalide macrolide has been shown to be effective in a single dose of $1 \mathrm{~g}^{150}$ but requires more assessment. It is, at present, not recommended for pregnant women and studies on its efficacy and safety in children are under way. A single dose regime will be the treatment of choice in the future as it will lead to better compliance.

Contact tracing, partner notification and other considerations

Chlamydial infection is a marker for other sexually transmitted diseases, hence screening for other common infections such as gonorrhoea is important.

It is essential to look for the source of infection. Checking for chlamydia and other concomitant sexually transmitted diseases in other family members in "non-sexual" cases, perpetrators in sexual abuse cases and sexual partners in cases acquired from voluntary sexual intercourse, is an integral part of management. In cases of neonatal ophthalmia, the parents and their other sexual partners should be screened. Advice on the use of condoms and nonoxynol-9 spermicide may further reduce transmission both of chlamydia and other sexually transmitted diseases.
In cases of suspected child sexual abuse, other professionals, such as the medical social worker, child psychiatrist and paediatrician may need to be involved.

\section{Follow-up}

Follow-up of patients is necessary to check compliance and to confirm that sexual partners have been screened. The necessity for a test of cure is controversial as treatment is highly effective. However, it will test for reinfection as well as reassure patients or parents of infected babies that the infection has been successfully treated. If a test of cure or for reinfection is to be performed, it should preferably take place at least two weeks after treatment, particularly if antigen detection tests are used as they can detect dead organisms. Their use as a follow-up test should be used with caution: a negative test is useful for excluding infection but a positive test should be further evaluated.

\section{Future developments}

Resources should be provided to implement screening programmes in high risk groups, now that antigen detection methods are available. The further development of cheap, rapid, sensitive, specific, non-invasive userfriendly techniques for diagnosing chlamydia infection is desirable for screening both high and low risk populations. In areas with a high prevalence of infection screening of pregnant women and adolescents, those with casual partners and babies with ophthalmia neonatorum or afebrile pneumonia should be implemented. In countries where LGV is common, prospective antenatal studies to ascertain the prevalence, transmission risk and disease syndromes due to the LGV serovars, if any, in the neonate, would further define its role in children.

New antimicrobials effective against $C$ trachomatis are needed which give prolonged high serum levels from a single dose. An alternative to erythromycin with less side effects is desirable for pregnant women. A simple, safe and cheap antibiotic may lead to the possibility of an eradication programme by mass treatment in high prevalence populations. Molecular research on chlamydial immune response with a view to developing a vaccine would be ideal but public acceptance of such a vaccine may be difficult.

1 Neisser ALS. Ueber eine der Gonorrhoe eigen-tumlich Microccus form. Zentralb Med Wissenschafen 1879;17: 497.

2 Kroner T. Zur atiologie der ophthalmoblennorrhoea neonatorum. Zentralbl Gynaekol 1884;8:643-5.

3 Halberstaedter L, von Prowazek S. Uber Zelleinschlusse parasitarer Natur beim Trachom. Arb Gesundheitsa parasitarer $\mathrm{Na}$.

4 Halberstaedter L, von Prowazek S. Uber Chlamydozoenbefunde bei blenorrhea neonatorum non gonorenbefunde bei blenorrhea neonatorum

5 Lindner $K$. Uebertragungsversuche von gonokokkenfreien blenorrhoea neonatorum auf Affen. Wein Klin Wochenschr 1909;22:1555.

6 Stargardt $K$. Uber Epithelzellveraanderungun beim Trachom und andern Konjuntivalerkrankungen. Graefe's Arch Ophtalmol 1909;69:525-42.

7 Heymann B. Ueber die fundorte der Powazek'schen 
Korperchen. Berl Klin Wochenschr 1910;47:663-6.

8 T'ang FF, Chang HL, Huang YT, Wang KC. Studies on the aetiology of trachoma with special reference to isolation of the virus in chick embryo. Chin Med $\mathscr{f}$ isolation of the

9 Gordon FB, Quan AL. Isolation of the trachoma agent in cell culture. Proc Soc Exp Biol Med 1965;118:354-9.

10 Wang S-P, Grayston JT. Immunologic relationship between genital TRIC, lymphogranuloma venereum and related organisms in a new microtitre indirect immunofluorescence test. Am $\mathcal{f}$ Ophthalmol 1970;70: 367-74.

11 Jones BR, Collier $\mathrm{LH}$, Smith $\mathrm{CH}$. Isolation of virus from inclusion blenorrhoea. Lancet 1959;i:902-5.

12 Dunlop EMC, Jones BR, Al-Hussaini MK. Genital finding in association with TRIC virus infection of the eye. III. Clinical and other findings. Preliminary report. $\mathrm{Br}$ f Venereal Dis 1964;40:33-42.

13 Dunlop EMC, Al-Hussaini MK, Freedman A, et al. Infections by TRIC agent and other members of the Bedsonia group with a note on Reiter's disease.: III. Genital infection and diseases of the eye. Trans Ophthal Soc UK 1966;86:321-34.

14 Botsztejn A. Die pertussoide, eosinophile pneumonie des sauglings. Ann Paediatr (Basel) 1941;157:28-46.

15 Schachter J, Lum L, Gooding CA, Ostler B. Pneumonitis following inclusion blennorrhea. $\mathcal{f}$ Pediatr 1975;87:779-80.

16 Beem MO, Saxon EM. Respiratory tract colonization and a distinctive pneumonia syndrome in infants infected with $C$ trachomatis. $N$ Engl $f$ Med 1977; 296:306-10.

17 Durand $M$, Nicolas J, Favre $M$. Lymphogranulomatose inguinale subaigue d'origine genitale probable, pentetre venerienne. Bull Mem Soc Med Hosp 1913;35: 274-88.

18 Frei $W$. Eine neue hautreaktion bei lymphogranuloma inguinale. Klin Wchnschr 1925;4:2148-9.

19 Weiss AG, Cain S. Adenopathie inguinale suppuree d'origine indeterminee. Bull Soc Franc Derm Syph 1925;32:161-5.

20 Lujan M, Rotter W. Lymphogranuloma inguinale bei kindern. Klin Wschnschr 1932;11:1387.

21 Chevallier P, Moricard R, Bernard J. Adenopathie inguinale ulceree chez une tres jeune enfant; reaction inguinale ulceree chez une tres jeune enfant; reaction 1233-6.

22 Levy H. Lymphogranuloma venereum in childhood. Review of the literature with report of a case. $\mathcal{F}$ Pediatr 1937;11:812-3.

23 Center for Disease Control. $C$ trachomatis infections Policy guidelines for prevention and control. MMWR 1985;34 (Suppl 3):53-74.

24 Department of Health. New cases seen at NHS genitourinary medicine clinics in England. 1990 Annual and December quarter figures. Summary information from KC60. Department of Health, London. 1991 SM12B.

25 Hammerschlag MR, Anderka M, Semine DZ, McComb D, McCormack WM. Prospective study of maternal and infantile infection with $C$. trachomatis. Pediatrics and infantile in

26 Schachter J, Grossman M, Holt J, Sweet R, Goodner E, Mills J. Prospective study of chlamydial infections in neonates. Lancet 1979;ii:377-80.

27 Schachter J, Grossman M, Sweet RL, Holt J, Jordan C, Bishop E. Prospective study of perinatal transmission of $C$. trachomatis. $¥ A M A$ 1986;255:3374-7.

28 Heggie AD, Lumicao GG, Stuart LA, Gyves MT. $C$ trachomatis infection in mothers and infants. A prospective study. Am $\mathcal{F}$ Dis Child 1981;135:507-11.

29 Gravett MG, Nelson HP, DeRouen T, Critchlow C, Eschenbach DA, Holmes KK. Independent associations of bacterial vaginosis and $C$. trachomatis infections with adverse pregnancy outcome. $\Im A M A$ 1986; tions with adverse

30 Hammerschlag MR, Chandler JW, Alexander ER, et al. Erythromycin ointment for ocular prophylaxis of neonatal chlamydial infection. $f A M A$ 1980;224 2291-3.

31 Berman SM, Harrison HR, Boyce WT, Haffner WJJ, Lewis M, Arthur JB. Low birth weight, prematurity and postpartum endometritis: association with perinatal cervical Mycoplasma hominis and C. trachomatis infections. $\mathcal{F} A M A$ 1987;257:1189-94.

32 Harrison HR, Boyce WT, Haffner WHJ, et al. The prevalence of genital $C$ trachomatis and mycoplasma infections during pregnancy in an American Indian population. Sex Transm Dis 1983;10:184-6.

33 Hardy PH, Hardy JB, Nell EE, Graham DA, Spense MR, Rosenbaum RC. Prevalence of six sexually transmitted agents among pregnant inner city adolescents mitted agents among pregnant inner city ado

34 Ross JM, Furr PM, Taylor-Robinson D, Altman DG, Coid CR. The effect of genital mycoplasmas on human fetal growth. Br $\mathcal{f}$ Obstet Gynaecol 1981;88: 749-55.

35 Wood PL, Hobson D, Rees E. Genital infections with $C$ trachomatis in women attending an antenatal clinic. $B r$ f Obstet Gynaecol 1984;91:1171-6.

36 Mardh P-A, Helin I, Bobeck S, Laurin J, Nilsson T. Colonization of pregnant and puerperal women and neonates with $C$ trachomatis. Br $\mathcal{V}$ Venereal Dis 1980 56:96-100.
37 Goh BT, Morgan-Capner P, Lim KS. Chlamydial screening of pregnant women in a sexually transmitted diseases clinic. Br ₹ Venereal Dis 1982;58:327-9.

38 Ballard RC, Fehler HG, Piot P. Chlamydial infection in the eye and genital tract in developing societies. In Oriel JD, et al. (eds) Chlamydial Infections. Cambridge, Cambridge University Press 1986:479-86.

39 Mabey DCW, Whittle HC. Genital and neonatal chlamydial infection in a trachoma endemic area. Lancet 1982;ii:300-1

40 Bentsi C, Klufio CA, Perine PL et al. Genital infections with $C$ trachomatis and $N$ gonorrhoeae in Ghanaian women. Genitourin Med 1985;61:48-50.

41 Leclerc A, Frost A, Collet M, Goeman J, Bedjabaga L Urogenital $C$ trachomatis in Gabon: an unrecognised epidemic. Genitourin Med 1988;64:308-11.

42 Jama $H$, Ismail SO, Isse $K$, Omar $K$, Lidbrink $P$, Bygdeman S. Genital $C$ trachomatis infection in pregnant women and female prostitutes in Mogadishu, Somalia. African $\mathcal{F}$ Sex Transm Dis 1987;2:17-25.

43 Laga M, Plummer FA, Nzanze $\mathrm{H}$ et al. Epidemiology of ophthalmia neonatorum in Kenya. Lancet 1986;ii 1145-9.

44 Thejls H, Gnarpe J, Gnarpe H, Larsson G. Age-related decrease in prevalence of $C$ trachomatis among pregnant women. Sex Transm Dis 1991;18:137.

45 Chaudhuri P, Sng EH, Yuen WS. $C$ trachomatis infection in unmarried women seeking abortions. Genitourin Med 1986;62:17-8.

46 Niamsanit S, Nunthapisud S, Limpongsanurak $S$ Prevalence of $C$ trachomatis among women attending Prevalence of $C$ trachomatis among women attending
an antenatal clinic in Bangkok. Southeast Asian $\mathcal{\exists}$ Trop Med Public Health 1988;19:609-13.

47 Gyaneswar R, Nsanze H, Singh KP, Pillay S, Seruvatu I. The prevalence of sexually transmitted agents in pregnant women in Suva. Aust $N Z \mathcal{F}$ Obstet Gynaecol 1987;27:213-5.

48 Winceslaus J, Goh BT, Dunlop EMC, et al. Diagnosis of ophthalmia neonatorum. $B$ M F 1987;295:1377-9.

49 Fransen L, Nsanze H, D'Costa LJ, Brunham RC, Piot P. Parents of infants with ophthalmia neonatorum: $A$ high risk group for sexually transmitted diseases. Sex Transm Dis 1985;12:150-4.

50 Hammerschlag MR, Alpert S, Rosner I, et al. Microbiology of the vagina in children: normal and potentially pathogenic organisms. Pediatrics 1978;62: potentially

51 Schachter J. Chlamydia. In: Rose NR, Friedman H (eds). Manual of Clinical Immunology. Washington DC, American Society for Microbiology, 1976

52 Wang S-P, Grayston JT, Alexander ER, Holmes KK Simplified microimmunofluorescence test with trachoma-lymphogranuloma venereum (C trachomatis) antigens for use as a screening test for antibody. $\mathcal{f}$ Clin Microbiol 1975;1:250-5.

53 Black SB, Grossman M, Cles L, Schachter J. Serologic evidence of chlamydial infection in children. $\mathcal{F}$ Pediatr 1981;98:65-7.

54 San Joaquin VH, Rettig PJ, Newton JY, Marks MI Prevalence of chlamydial antibodies in children. $A m \mathcal{F}$ Dis Child 1982;136:425-7.

55 Grayston JT, Wang S-P, Foy HM, Kuo CC. Seroepidemiology of $C$ trachomatis infection. In Mardh PA, et al (eds). Chlamydial infections. Amsterdam, Elsevier Biomedical Press. 1982:405-19.

56 Burney P, Forsey T, Darougar S, Sittampalam Y, Booth $\mathbf{P}$, Chamberlain $\mathbf{R}$. The epidemiology of chlamydial infections in childhood: A serological investigation. In f Epidemiol 1984;13:4915.

57 -Shafer M-A, Prager V, Shalwitz J, et al. Prevalence of urethral $C$ trachomatis and $N$. gonorrhoeae among asymptomatic, sexually active adolescent boys. $\mathcal{F}$ Infect Dis 1987;156:223-4.

58 Chacko MR, Lovchik JC. C trachomatis infection in sexually active adolescents: prevalence and risk factors. ally active adolescents: p
Pediatrics 1984;73:836-40.

59 Frazer JJ, Rettig PJ, Kaplan DW. Prevalence of cervical $C$ trachomatis and Neisseria gonorrhoeae in female $C$ trachomatis and Neisseria gonorrho
adolescents. Pediatrics 1983;71:333-6.

60 Blythe MJ, Katz BP, Orr DP, Caine VA, Jones RB Historical and clinical factors associated with $C$ trachomatis genitourinary infection in female adolescents. $f$ Pediatr 1988;112:1000-4

61 Oh K, Feinstein R, Soileau E, Clonal G, Pass R. C trachomatis cervical infection and oral contraceptive use among adolescent girls. F Adolesc Health Care 1989, 10:376-81.

62 Saltz GR, Linnemann CC, Brookman RR, Rauh JL. C trachomatis: cervical infections in females. 7 Pediatr 1981;98:981-5.

63 Shafer MA, Beck A, Blain B, et al. C trachomatis: Important relationships to race, contraception, lower genital tract infection and Papanicolaou smears. $\mathcal{F}$ Pediatr 1984;104:141-6.

64 Mulcahy FM, Lacey CJN. Sexually transmitted infections in adolescent girls. Genitourin Med 1987;63 119-21.

65 Rahm VA, Odlind V, Petterson R. $C$ trachomatis in sexually active teenage girls. Factors related to genita chlamydial infection. Genitourin Med 1991;67:317-21.

66 Sonck CE. Five cases of lymphogranuloma inguinale in children (with rectal manifestations and arthropathies). Acta Derm Venereol (Stokh) 1939;20:171-90.

67 Greenblatt RB, Pund ER, Sanderson ES, Torpin R, 
Dienst RB. Management of chancroid, granuloma inguinale, lymphogranuloma venereum in general inguinale, ymphogranuloma venereum in general practice. Public Health Service Publication No. 255,

68 Annamunthodo H, Stewart DB. Lymphogranuloma venereum in children. In: Sigel $M M$, ed. Lymphogranuloma venereum. Coral Gables, Florida. University of Miami Press. 1962;169-71.

69 Dick W. 1st das lymphogranuloma inguinale auf die nachkommenschaft ubertragbar? Med Clin 1936;32: 319-20.

70 Michelson ID, Crotty JG, Kasselberg LA. Pregnancy in lymphopatia venerea, complicated by esthiomene and rectal stricture. Am f Obstet Gynecol 1938;35:322-6.

71 Coutts WE, Monetta O. Hereditary transmission of lymphogranulomatosis venerea. $\mathcal{F}$ Trop Med Hyg 1938;41: $279-80$.

72 Alacoque B, Cloppet H, Dumontel D, et al. Histological, immunofluorescent and ultrastructural features of lymphogranuloma venereum: a case report. $B r \mathcal{F}$ Venereal Dis 1984;60:390-5.

73 Heaton S, Hammerschlag MR, Roblin PM, Di Pasquale RC. Lymphogranuloma in a pregnant woman. Sex Transm Dis 1988;15:148-9.

74 Schachter J. Isolation of Bedsoniae from human arthritis and abortion tissues. Am $\mathcal{F}$ Ophthalmol 1967;63: $1082-6$.

75 Harrison HR. Chlamydial infection in neonates and children. In: Oriel JD et al (eds). Chlamydial Infections. dren. In: Oriel JD et al (eds). Chlamydial Infections. 283-92.

76 Berman SM, Harrison HR, Boyce WT, Haffiner WJJ, Lewis M, Arthur JB. Low birth weight, prematurity, and postpartum endometritis. Association with prenatal cervical $M$ hominis and $C$ trachomatis infections. ҰAMA 1987;257:1189-94.

77 Thorp JM, Katz VL, Fowler LJ, Kurtzman JT, Bowes WA. Fetal death from chlamydial infection across intact amniotic membranes. Am $\mathcal{f}$ Obstet Gynecol 1989;161:1245-6.

78 Mardh P-A, Johansson PJH, Svenningsen N. Intrauterine lung infection with $C$ trachomatis in a premature infant. Acta Paediatr Scand 1984;73:569-72.

79 van der Bel-Kahn JM, Watanakunakorn C, Menefee MG, Long HD, Dicter R. C trachomatis endocarditis. Am Heart $¥$ 1978;95:627-36.

80 Rosenbery AM, Petty RE. Reiter's disease in children. Am $\mathcal{F}$ Dis Child 1979;133:394-8.

81 Vilppula AH, Yli-Kerttula UI, Ahlroos AK, Terho PE. Chlamydial isolations and serology in Reiter's syndrome. Scand $\mathcal{F}$ Rheumatol 1981;10:181-5.

82 Keat A, Thomas B, Dixey J, Osborn M, Sonnex C, Taylor-Robinson D. C trachomatis and reactive arthritis: the missing link. Lancet 1987; i:72-4.

83 Rees E, Tait IA, Hobson D, Byng RE, Johnson FWA. Neonatal conjunctivitis caused by $N$ gonorrhoeae and $C$ trachomatis. Br $¥$ Venereal Dis 1977;53:173-9.

84 Frommell GT, Rothenberg R, Wang S, McIntosh K Chlamydial infections of mothers and their infants. $f$ Pediatr 1979;95:28-32.

85 Chandler JW, Alexander ER, Pheiffer TA, Wang S-P, Holmes KK, English M. Ophthalmia neonatorum associated with maternal chlamydial infections. Trans Am Acad Ophthalmol Otolaryngol 1977;83:302-8.

86 Datta $\mathrm{P}$, Laga M, Plummer FA, et al. Infection and disease after perinatal exposure to $C$ trachomatis in Nairobi, Kenya. F Infect Dis 1988;158:524-8.

87 Dunlop EMC, Harper IA, Al-Hussaini MK, et al. Relation of TRIC agent to non-specific genital infection. Br $\mathcal{Y}$ Venereal Dis 1966;42:77-87.

88 Freedman A, Al-Hussaini MK, Dunlop EMC, et al. Infections by TRIC agent and other members of the Bedsonia group with a note on Reiter's disease. II. Genital infection and diseases of the eye. Trans Genital infection and diseases

89 Mordhorst $\mathrm{CH}$, Wang S-P, Grayson JT. Childhood trachoma in a non-endemic area. $\mathscr{F A M A}$ 1978;239: 1765-71

90 Hammerschlag MR, Doriaswamy B, Alexander ER, Cox P, Price W, Gleyzer A. Are rectogenital chlamydial infections a marker of sexual abuse in children? Pediatr Infect Dis 1984;3:100-4.

91 Ingram DL, Runyan DK, Collins AD, et al. Vaginal $C$ trachomatis infection in children with sexual contact. Pediatr Infect Dis 1984;3:97-9.

92 Fuster CD, Neinstein LS. Vaginal $C$ trachomatis prevalence in sexually abused prepubertal girls. Pediatr 1987;79:235-8.

93 Ingram DL, White ST, Occhiuti AR, Lyna PR. Childhood vaginal infections: association of C. trachomatis with sexual contact. Pediatr Infect Dis 1986;5: 226-9.

94 Bell TA, Stamm WE, Kuo CC, Holmes KK, Grayston JT. Chronic $C$ trachomatis infections in infants. In: Oriel JD, et al. (eds). Chlamydial Infections. Cambridge, Cambridge University Press. 1986:305-8.
Sternberg K, Mardh P-A. Persistent neonatal chlamydial infection in a 6 year old girl. Lancet 1986;ii: 1278-9.

96 Favre $M$, Hellerstrom S. The epidemiology, aetiolog and prophylaxis of lymphogranuloma venereum. Acta Derm Venereol (Stockh) 1954;34 (Supp 30):1-60.

97 Elitzak J, Kornblith BA. Lymphogranuloma inguinale with rectal manifestations in a child. Am $\mathcal{F}$ Dis Child 1935;49:703-9.
98 Banciu A, Caratzali A. Un case de maladie de Nicolas et Favre a manifestations multiples. Ann Derm et Syph (Fr) 1938;9:100-5.

99 Martin DH, Koutsky L, Eschenbach DA, et al. Prematurity and perinatal mortality in pregnancies complicated by maternal $C$ trachomatis infections. $\mathfrak{f A M A} 1982 ; 247: 1585-8$

100 Martin DH, Pastorek JG, Faro S. Risk factors for $C$ trachomatis in high risk populations of pregnant women. In: Oriel JD, et al. (eds). Chlamydia Infections. 189-92.

101 Harrison HR, Alexander ER, Weinstein L, Lewis M, Nash M, Sim DA. Cervical $C$ trachomatis and mycoplasma infections in pregnancy: epidemiology mycoplasma infections in pregnancy:

102 Sweet RL, Landers DV, Walker C, Schachter J. C trachomatis infection and pregnancy outcome. Am $\mathcal{F}$ Obstet Gymecol 1987;156:824-33.

103 Thompson S, Lopez B, Wong K-H, et al. A prospective study of chlamydial and mycoplasma infections during pregnancy. In: Mardh P-A, et al, eds. Chlamydial Infections. Amsterdam, Elsevier Biomedical Press. 1982;155-8.

104 Armstrong JH, Zacarias F, Rein MF. Ophthalmia neonatorum: A chart review. Pediatrics 1976;57:884-92.

105 Rowe DS, Aicardi EZ, Dawson CR, Schachter J. Purulent ocular discharge in neonates: significance of Purulent ocular discharge in neonates:

106 Mordhorst CH, Dawson C. Sequelae of neonatal inclusion conjunctivitis and associated disease in parents. sion conjunctivitis and associated

107 Schachter J, Grossman M, Holt J, Sweet R, Spector S. Infection with $C$ trachomatis: Involvement of multiple anatomic sites in neonates. $\mathcal{F}$ Infect Dis 1979;139: $232-4$

108 Kent SE, Matthews RS. Chlamydial rhinitis neonatorum. F Laryngol Otol 1987;101:1193-7.

109 Schaefer C, Harrison R, Boyce WT, Lewis M. Illness in infants born to women with $C$ trachomatis infection. Am $\mathcal{F}$ Dis Child 1985;139:127-33.

110 Chang MJ, Rodriguez WJ, Mohla C. $C$ trachomatis in otitis media in children. Pediatr Infect Dis 1982;1:95-7.

111 Dunlop EMC Harris RJ Darougar S, Treharne JD, AlEgaily SS. Subclinical pneumonia due to serotypes D$\mathrm{K}$ of $C$ trachomatis: case report of two infants. $\mathrm{Br} \mathcal{F}$ Venereal Dis 1980;56:337-40.

112 Attenburrow AA, Barker CM. Chlamydial pneumonia in the low birth weight neonate. Arch Dis Childhood 1985; 60:1169-72.

113 Klingebiel T, Pickert A, Dopfer R, Ranke MB, Siedner $R$. Unusual course of a chlamydia pneumonia in an infant with Ig G2/Ig G4-deficiency. Eur $f$ Pediatr 1989;148:431-4.

114 Numazaki K, Chiba S, Kogawa K, Umetsu M, Motoya $H$, Nakayo T. Chronic respiratory disease in premature infants caused by $C$ trachomatis. $₹$ Clin Path 1986;39:84-8.

115 Tipple MG, Beem MO, Saxon EM. Clinical characteristics of the afebrile pneumonia associated with $C$ tratics of the afebrile pneumonia associated with $C$ tra-
chomatis infection in infants less than 6 months of age. chomatis infection in infants

116 Hardy GC. Vaginal flora in children. Am $\mathcal{F}$ Dis Child 1941;62:939-54

117 Rettig PJ, Nelson JD. Genital tract infection with $C$ trachomatis in prepubertal children. $f$ Pediatr 1981;99: 206-10.

118 Hammerschlag $M$, Hammerschlag $P$, Alexander ER The role of $C$ trachomatis in middle ear effusion in children. Pediatrics 1980;66:615-7.

119 Wells SC. $C$ trachomatis as an aetiological agent of "glue ear" infections in children. $\mathcal{F}$ Laryngol Otol 1986; 100: $1341-6$.

120 Blackstone ML, Lovchik JC, Gray WC. Presence of $C$ trachomatis in tympanocentesis fluid assessed by immunofluorescence microscopy and culture. Otolaryngol Head Neck Surg 1989;100:348-9.

121 Ogawa $\mathrm{H}$, Hashiguchi $\mathrm{K}$, Kazuyama Y. Isolation of $C$ trachomatis from the middle ear aspirates of otitis media. Acta Otolaryngol (Stockh) 1990;110:105-9.

122 Grayston JT, Mordhorst CH, Wang S-P. Childhood myocarditis associated with $C$ trachomatis infection. fAMA 1981;246:2823-7.

123 Miller BR, Arthur JD, Perry WH, Perez TR, Mosman PL. Atypical croup and $C$ trachomatis. (letter) Lancet 1982;i:1022.

124 Katzman DK, Friedman IM, McDonald CA, Litt IF. $C$ trachomatis Fitz-Hugh Curtis syndrome without salpintrachomatis Fitz-Hugh Curtis syndro

125 Tack KJ, Peterson PK, Rasp FL, et al. Isolation of $C$ trachomatis from the lower respiratory tract of adults. trachomatis from the

126 Embil JA, Thiebaux HJ, Mannel FR, Pereira LH, MacDonald SW. Sequential cervical specimens and the isolation of $C$ trachomatis: factors affecting detection. Sex Transm Dis 1983;10:62-6.

127 Munday PE, Cardner JM, Hanna NF, Taylor-Robinson $D$. Is one swab enough to detect chlamydial infection of the cervix. Br $\mathcal{F}$ Venereal Dis 1984;60:384-6.

128 Dunlop EMC, Goh BT, Darougar S, Woodland R Triple culture tests for diagnosis of chlamydial infection of the genital tract. Sex Transm Dis 1985;12. 68-71.

129 Goh BT, Dunlop EMC, Darougar S, Woodland R. 
Three sequential methods of collecting material from the urethra of men for culture for $C$ trachomatis. Sex Transm Dis 1985;12:173-6.

130 Centre for Disease Control. False positive results with the use of chlamydia tests in the evaluation of suspected sexual abuse-Ohio 1990. MMWR 1991;39:932-5.

131 Stamm WE. Diagnosis of $C$ trachomatis genitourinary infections. Ann Intern Med 1988;108:710-7.

132 Hammerschlag MR, Rettig PJ, Shields ME. False positive results with the use of chlamydial antigen detection tests in the evaluation of suspected sexual abuse in children. Pediatr Infect Dis 1988;7:11-4.

133 Caul EO, Paul ID, Milne JD, Crowley T. Non-invasive sampling method for detecting $C$ trachomatis. (letter) sampling method for

134 Paul ID, Caul EO. Evaluation of three $C$ trachomatis immunoassays with an unbiased, non-invasive clinical sample. F Clin Microbiol 1990;28:220-2.

135 Chernesky M, Castriciano S, Sellors J, Stewart I, Landis S, Seidelman W, Grant L, Devlin C, Mahony J. Detection of $C$ trachomatis antigens in urine as an alternative to swabs and cultures. F Infect Dis 1990;161: $124-6$.

136 Hay PE, Thomas BJ, Gilcrest C, Palmer HM, Gilroy $C B$, Taylor-Robinson $D$. The value of urine samples from men with non-gonococcal urethritis for the detecfrom men with non-gonococcal urethritis for the dete-

137 Patel R, Kinghorn GR, Kudesia G, VanHegan R. C trachomatis detection and non-invasive sampling methods. (letter) Lancet 1991;i:1169.

138 Arya OP, Mallinson H, Andrews BE, Sillis M. Diagnosis of urethritis: role of polymorphonuclear counts in gram stained urethral smears. Sex Transm Dis 1984;11: 10-7. 139 Swartz SL, Kraus SJ, Herrmann KL, Stargel MD, gonococcal urethritis. $\mathcal{F}$ Infect Dis 1978;138:45-54.

$140 \mathrm{Goh}$ BT. The genitalia and sexually transmitted diseases.
In: Swash M, Mason S, eds. Hutchison's clinical methods. London. Bailliere Tindall. 19th Edition 1989, 552-68.

141 Rodin P. Asymptomatic non-specific urethritis. $B r f$ Venereal Dis 1971;47:452-3.

142 Adger H, Shafer M-A, Sweet RL, Schachter J. Screening for $C$ trachomatis and $N$ gonorrhoeae in adolescent males: value of first catch urine examination. Lancet 1984;ii:944-5.

143 Brunham RC, Paavonen J, Stevens CE, et al. Mucopurulent cervicitis-the ignored counterpart in women of urethritis in men. N Engl $\mathcal{F}$ Med 1984;311: 1-6.

144 Nugent RP, Hillier SL. Mucopurulent cervicitis as a predictor of chlamydial infection and adverse pregnancy dictor of chlamydial infection and adverse

145 Podgore JK, Holmes KK, Alexander ER. Asymptomatic urethral infections due to $C$ trachomatis in male US military personnel. $\mathcal{F}$ Infect Dis $1982 ; 146: 828$.

146 Estany A, Todd M, Vasquez M, McLaren R. Early detection of genital chlamydial infection: an economic evaluation. Sex Transm Dis 1989;16:21-7.

147 Dunlop EMC, Goldmeier D, Darougar S, Jones BR Chlamydial infection of the genital tract in the mothers and fathers of babies suffering from ophthalmia neonatorum due to TRIC agent. In: Catterall RD Nicol CS eds. Sexually transmitted diseases. London: Academic Press, 1976:83-8.

148 Laga M, Plummer FA, Piot $P$, et al. Prophylaxis of gonococcal and chlamydial ophthalmia neonatorum: silver nitrate versus tetracycline. $N$ Engl $¥$ Med 1988;318: nitrate

149 Hammerschlag MR, Cummings C, Roblin PM, Williams TH, Delke I. Efficacy of neonatal ocular prophylaxis for the prevention of chlamydial and gonococcal conjunctivitis. N Engl f Med 1989;320:769-72.

150 Whatley JD, Thin RN, Mumtaz G, Ridgway GL Azithromycin vs doxycycline in the treatment of nongonococcal urethritis. Int $f$ STD EO AIDS 1991;2: 248-51. 